\title{
Review of Literature of Faculty Motivation for Doing Research in Universities
}

\author{
Thi Kim Nhung Tran, Thanh Do Nguyen, Manh Dung Tran \\ National Economics University, Vietnam \\ Thanh Van Pham, Ngoc Thang Ha, Thi Lien Huong Nguyen \\ National Economics University, Vietnam
}

\begin{abstract}
Faculty research in the universities plays a very important role in the education and development of every country in the world. The purpose of this research is to review studies in this field, different approaches in studies, and fundamental theories used for studies. The results obtained from the literature review show that many scholars have conducted researches on the determinants influencing the faculty productivity to do research. Most of studies apply the theories of working motivation. However, not many scholars conduct research on the faculty motivation to do research. The final result of this research provides follow-up suggestions for studies of the motivation for conducting research on the side of lecturers, thereby guiding managers to enhance faculty motivation to do research. Keywords: Motivation, productivity, research, lecturer/faculty.
\end{abstract}

DOI: $10.7176 / \mathrm{EJBM} / 11-20-10$

Publication date:July $31^{\text {st }} 2019$

\section{Introduction}

Research on the working motivation is not a new topic. In contrast, this is a topic that has been studied for a long time. However, the motivation of conducting research is a unique topic which can attract a lot of researchers. The literature review shows that there are many studies of faculty research. However, the majority of these studies are about the determinants affecting the faculty productivity to do research. They are inclusive of studies done by Broder and Ziemer (1982); Cargile and Bublitz (1986); Feldman and Paulsen (1999); Olorunsola \& Bamijoko (2005); Chen et al. (2006); Hu and Gill (2000); Tien (2000), Henley and Nyaw (1987).

Particularly, the majority studies of faculty productivity to do research apply the theories of working motivation from different perspectives. The studies apply many theories of needs, such as Maslow's Need Hierarchy Theory and Herzberg's two-factor theory (Khan, 2011), etc. and theories of motivation in process; such as Skinner's Reinforcement Theory (Blackburn \& Lawrance, 1995), Self-confidence Theory (Blackburn \& Lawrance, 1995; Williams, 2003; Lertputtarak, 2008), Victor Vroom's Expectancy Theory (Blackburn \& Lawrance, 1995; Hu \& Gill, 2000; Williams, 2003; Lertputtarak, 2008; Tien, 2000; Chen et al., 2006; Ramli \& Jusoh, 2015).

In fact, there are many studies on research activities but there are just a few studies focus on the motivation of conducting research. On the other hand, studies of research productivity only apply the motivation theories. Therefore, the purpose of this report is to summarize the determinants affecting the motivation of conducting research and to distinguish these determinants from those affecting the research productivity.

\section{Determinants influencing research implementation on the side of lecturers}

The concept of "science" has existed since ancient times and in general, researchers often agree that the concept of "science" is a system of knowledge about nature, society, thought and objective development rules about nature, society and thought. This system of knowledge had been formed earlier in the history and has been constantly developed based on social practices.

Any academic research that is conducted by lecturers and contributes to the creation of new knowledge of phenomenal rules is considered as faculty research (Creswell, 1986; Lertputtarak, 2008, p. 22). For examples, they may be: research proposals for a grant, i.e. research at all levels or programs and projects; a publication published in the journal with/without reviewers; research reports; monographs, textbooks or participation in compiling a chapter of books, articles in magazines and seminars; useful inventions and products; guidebooks for students and postgraduate researchers to do research (Creswell, 1986; Lertputtarak, 2008, p. 22). Lertputtarak (2008) defines faculty research as any academic activity conducted by the faculty to do research, namely identifying research problems, searching for research documents, collecting research data, conducting data analyses or writing scientific reports. Thus, it can be seen that faculty research can be expressed in these following forms (i) doing research projects; (ii) publishing research works; (iii) useful inventions and products; (iv) compiling books and textbooks; (v) guiding students to do research.

When studying scientific research productivity, many scholars apply motivation theories to get a deep knowledge of the determinants affecting the research productivity, for example, Chen et al. (2006) using Victor 
Vroom's Expectancy Theory (1964); Tien (2000) using both Victor Vroom's Expectancy Theory (1964) and Reinforcement Theory; Pasupathy \& Siwatu (2014) using Self-confidence Theory; Lertputtarak (2006) combining motivation theories such as Victor Vroom's Expectancy Theory (1964) with Self-confidence Theory in qualitative research. Zhang (2014) synthesized a model consisting of three groups of determinants affecting research implementation on the side of lecturers, including: internal motivation (perceiving the achievements, interest and curiosity, making contributions to society, be pursuing goals, getting autonomy at work), external motivation (receiving promotion, getting monetary bonuses, having tenure, being recognized by colleagues and society) and other productivity determinants (confidence, social networks, age, research support, teaching load, faculty scale, culture) (Figure 1).

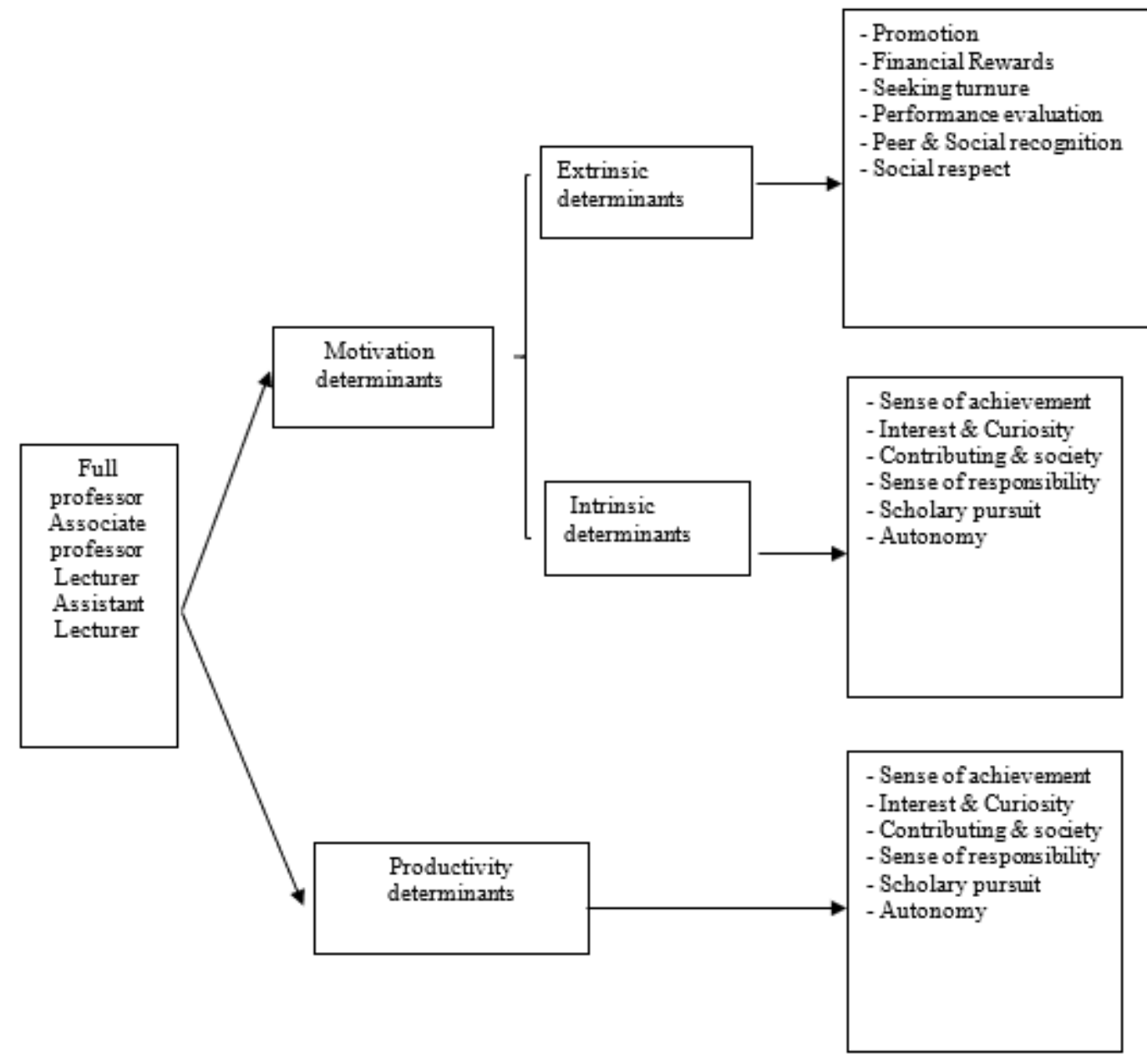

Figure 1: Determinants motivating research and influencing research productivity Zhang (2014)

\section{Working motivation and Motivation of conducting research on the side of lecturers}

\subsection{Working motivation}

Human motivation theories have been explored from two perspectives: psychological and behavioral. The definition of "motivation" is considered as a starting point for conducting research on these theories. However, different researchers and psychologists have provided very different definitions of this word. Choosing a suitable definition for research is very important because it can help determine how to measure motivation. Therefore, we will summarize and discuss some definitions of motivation.

Motivation as a state of inner mind makes a person behave in a way to achieve goals as set (James, 2011). James thinks motivation is what motivates a person to act, and to give reasons for behaviors. He also adds that motivation is not manipulation and imitation but it is the understanding of needs that maks people act.

Butkus and Green (1999) also state that motivation is derived from the word "motivate", which also means to move, push or persuade to act to satisfy a need. Mol (1992) differentiates between the words "motive" and "motivation". He describes "motive" as carrying out a task in order to be remunerated while "motivation" is attributed to the highly enthusiastic involvement of a person to carry out a task. Simply, "motive" is to force a person to carry out a task while "motivation" is the voluntary involvement, and decision of a person to carry out a task (Robbins \& Judge, 2008). Researchers emphasize that motivation is the basis for success because participants 
are happy and voluntary, but they are not be forced to carry out a task in order to be remunerated. Therefore, La Motta (1995) defines motivation as a reason for individuals' accomplishments to carry out the project.

Adler (2008) describes motivation as an instinctive motivation, pushing people to act in a certain direction. He argues that motivation is a force to cope with the guilt feelings. Lockwood (2005) identifies that motivation represent forces affecting the external or internal aspects of a person so that he or she acts in a specific way. Baron (1983) has his own definition of motivation. He defines motivation as a set of processes concerned with a kind of force that energizes behavior and directs it towards achieving specific goals. Many scholars have considered motivation as a goal-directed behavior. This characteristic of motivation is also suggested by Kreitner and Kinicki (2001, p. 162) that motivation represents "those psychological processes that cause the stimulation, persistence of voluntary actions that are directed by goals".

It can be seen that in general, motivation is basically related to factors or events which move, direct or push a person to act in a specific way. Moreover, definitions show that it is necessary to have an invisible force to push people to act (Bailey, 1999). When it is believed that employees are motivated naturally, an organization simply provides an environment for their motivation to be strengthened and improved (Baron, 1983). It means that employees are more motivated to perform behaviors when an organization creates an environment and provides a better working atmosphere. Lawler (2003) notes that different theories ask questions about the reason why people love their work, why they seek special rewards and why they feel satisfied or dissatisfied with their jobs and rewards. Here are some questions that create a lot of assumptions and hypotheses for research. However, there are many motivation aspects in an organization. A person which is motivated by those aspects may not necessarily encourage others, because there are many different factors that influence the motivation level of employees (La Motta, 2009).

Under the meaning of "process" (process theories), motivation has been described as a set of processes that arouse, direct, and maintain human behaviours to achieve goals" (Greenberg \& Baron, 1993, p. 114). Similarly, Mitchell (1997) defines motivation as the "direction", intensity, and persistence of work-related behaviors required by an organization". This definition is based on the human psychological development. Over the years, different scholars have offered about 140 definitions of motivation (George \& Jones, 2005), most of which focus on the concept of strengthening and maintaining efforts for some behaviors towards attaining the desired goals.

Many studies have divided motivation into external motivation and internal motivation. External motivation refers to one which is driven by external factors (external rewards) and internal motivation refers to one that is driven by internal factors (internal rewards) (Mitchell \& Albright, 1972). Wernimont (1972) argues that all internal factors are individuals' inner emotions while external factors are external specific situations. Internal motivation is often related from the work itself, the pleasure and satisfaction derived from participation (Vallerand, 1997; Deci \& Ryan, 1985). So it refers to a process rather than an output.

\subsection{Motivation of conducting research on the side of lecturers}

Under the meaning of "process" (process theories), research motivation can be understood as a process where an individual is stimulated and oriented, continuously puts more effort and shows more perseverance into research activities. So, what motivates lecturers to invest a great deal of effort and perseverance in conducting research? In many studies, external motivation and internal motivation have been mentioned.

3.2.1. External motivation

A literature review of external motivation to do research on the side of staff/employees is provided in detail by Feldman \& Paulsen (1999). External motivation refers to behavior that is driven by external rewards such as tenure, promotion, remuneration, work-trip allowances, allowances and professional expenses and other special interests. In her study, Chen et al. (2006) concludes that external motivation is inclusive of getting better salary raises, having tenure and receiving promotion. Similarly, it can be seen in Henley and Nyaw's study (1987) that Chinese employees have placed great emphasis on material incentives such as salary increment and bonuses over nonmaterial stimuli such as recognition. Mallaiah \& Yadapadithaya (2009) mentions that bonuses and gifts, praise, public recognition, and career development opportunities are external rewards. Olorunsola and Bamijoko (2005) argue that external motivation such as highly-paid salary, retirement benefits, overtime allowances and good working conditions are often important factors to attract and retain best people. In summary, external motivation summarized from studies is shown below in detail:

\section{Salary Increment}

Salary increment is mentioned in many studies by Baker (1994), Cargile \& Bublitz (1986), Chen et al. (2006), Hu \& Gill (2000), Tien (2000), Brewer (1990), Ramli et al. (2015), Ghaoddousi et al. (2014), Feldman \& Paulsen (1999), Henley \& Nyaw (1987), Olorunsola \& Bamijoko (2005). Paying salary is a usual way to motivate someone. People's motivation then can be controlled largely by offering or withholding financial rewards. (Rowley, 1996). In many previous studies, scholars suggest that salary increment is considered as a significant factor affecting lecturers (Baker, 1994; Cargile \& Bublitz, 1986; Chen et al., 2006; Hu \& Gill, 2000; Tien, 2000). It makes researchers be satisfied and believed that universities have paid more attention to and have confidence in their 
capabilities (Ramli \& Jusoh, 2015). In Brewer's study (1990), 42\% of survey participants believe that the presence of an appropriate pay system promotes the intensity of faculty research.

\section{Getting monetary bonuses}

The factor of getting monetary bonuses is discussed in many studies by James (2011), Deeprose (1994), Zhang (2008); Ghaoddousi et al. (2014), Henley \& Nyaw (1987); Olorunsola \& Bamijoko (2005). Awarded scientists will be more productive and vice versa (James, 2011). Deeprose (1994) realizes that an effective reward system improves employee motivation. This has contributed to improve the operational performance of an organization. Zhang (2008) suggests that to attract and retain researchers, two special measures for stimulating research activities are allocating research funds and giving direct monetary rewards for research results.

\section{Receiving Promotion or Permanent Staff Status}

Dennis et al. (2006), Cargile \& Bublitz (1986), Hu \& Gill (2000), Tien (2000), Fox (1985), Ruscio (1987), Sharpes (1987), Cooper \& Burger (1980), Tien \& Blackburn (1996), highly emphasize the role of receiving promotion in their studies. Dennis et al. (2006) claims that receiving promotion is an important event for most of the lecturers. Receiving promotion is often based on research results such as publishing publications. Previous studies have shown that receiving promotion and having tenure are one among many determinants motivating lecturers to do research (Cargile \& Bublitz, 1986; Hu \& Gill, 2000; Tien, 2000). Fox (1985) suggests that higher education institutions can affect faculty research behavior through methods of promotions. In Ruscio's qualitative research (1987), a researcher makes comments on research publications with the content: "Half of three quarter of what I read, if I asked myself why this was written, the answer normally is "promotion" ". A study in China shows that receiving promotions leads to higher salaries, higher social status, better working conditions, more power, more respect from colleagues and students, and more other benefits. Lecturers' receiving promotions are directly related to the income and benefits of university lecturers in China (Zhang, 2014). The most important thing is that a higher rank can lead to a increase of basic salary level. It is clear that there are other issues related to the ranks of lecturers, namely position and political power (Sharpes, 1987). Chen (2006) argues that receiving promotion can boost the research productivity because research output is considered to be the most important indicator in academic promotion assessment.

From the view of reinforcement theory, Cooper \& Burger (1980) suggests that changing awards of receiving promotion affects the rate of research products made public. According to Tien and Blackburn's survey (1996), the expected publication rate remains low in the early period of the interval in rank because no promotion reward is conferred. In general, the nearer the time of promotion, the higher is the publication rate. Similarly, Bentley \& Blackburn (1991) argue that the motivational effect of promotion depends on an individual's need for promotion. If a person does not receive promotion, she or he will not conduct research and publish his/her research output. This is the same as Tien's finding (2000), indicating that those who attach more importance to promotion will publish their research output more than those who do not.

\section{Receiving or having tenure}

Similar to receiving promotion, having tenure is also emphasized in a lot of studies by Chen et al. (2006), Santo et al. (2009), Bess (1998), Ramli et al. (2015). In the study of Chen et al. (2006), the majority of faculty members suggest that once being tenured, they cannot be fired whether they work or not. Consequently, tenured faculty members have little incentive to perform work tasks. Same as the Santo's finding in 2009 that the increased professional rank decreases the research productivity. This indicates that once faculty members were no longer worried about receiving tenure, their motivation to publish decreased. Chen (2006) concludes that the tenured faculty members are more motivated by internal rewards while untenured faculty members are more motivated by external rewards. Discussing tenure versus contract systems for faculty, Bess (1998) states that it is not the security of tenure that reduces faculty motivation and productivity. Instead, the explanation of low motivations lies in the absence of necessary organizational contextual conditions and thus sharply reduce motivation. Thus, receiving tenure have different effects on the working motivation of lecturers and such differences occur in different contexts. Holding an Administrative Post

In the studies of Chen et al. (2006), Chiang \& Jang (2008), Ghaoddousi et al. (2014), Ramli et al. (2015), Feldman \& Paulsen (1999), the factor of holding an administrative post has been mentioned. Chen (2006) argues that holding an administrative post is the least important determinant for lecturers, so it has the least impact on research productivity. This is true because the nature of administrative tasks is different from that of research activities even though they complement each other. However, if lecturers are responsible for many administrative management tasks, it will make lecturers spend less time on research activities.

\section{Getting reduced teaching load}

Hu \& Gill (2000) conducts a survey on determinants affecting the research productivity of lecturers. They realize that teaching load is one of the determinants that significantly reduce research productivity. Other researchers such as Chen (2006) and Cargile \& Bublitz (1986) also determine that reducing teaching load is one of the determinants which increase the motivation of conducting research.

Getting chaired professorship 
Getting chaired professorship is one of the important determinants which affect the motivation of conducting research (Chen et al., 2006; Hemmings \& Hill, 2009). In science there are no geographical boundaries, so it is not limited to those in the organization of individual researchers but also around the world. Through internet, scientific journals, publications and other academic conferences, the academic community is becoming wider around the world, so it is extremely important to get a chaired professorship. Most of the academic staff wants that their achievements should be recognized in their academic records. Therefore, according to Tien's study (2008), receiving social evaluation and recognition are also important factors to encourage lecturers to do research, especially for lecturers with academic titles and degrees.

The higher level is to get chaired professorship at a national and international level. Through excellent research output, a university as well as a researcher can gain their recognition in a specific academic field at a national and international level (Chen et al., 2006; Hu \& Gill, 2000; Tien, 2000). Getting chaired professorship will create a good reputation and encourage lecturers to do research more actively and effectively.

\section{Satisfying need to stay current}

Chen et al. (2006) argues that one of the factors motivating lecturers to do research is to satisfy needs that are required to maintain their current job. Studies require a comprehensive literature review of relevant studies, thus make researchers compare, analyze and find knowledge gaps in research. In addition, through future research suggested for a study published in journals, people have known the expertise and capabilities of a researcher and it keeps him/her in touch with the current questions and other relevant topics (Ramli et al., 2015).

\section{Finding a better position at other university}

Finding a better job at another university can be an external reward because a better job can be understood as higher payment, better research support, and reduced teaching load. However, a better job may also mean being more relaxed in spirit, which is an internal reward. Therefore, we separate this reward from other external rewards because it cannot be a part of the current reward system in the universities that lecturers are working at (Chen et al., 2006). According to Chen et al. (2006), finding a better position at other universities is one of the least important factors for lecturers to conduct research. However, lecturers who have not had any academic titles and degrees realize that finding a better job at a university is more important than lecturers with higher academic titles. The reason is that lecturers who have had high academic titles and degrees such as Professors or Associate Professors have stabilized their position. However, lecturers who have not had any academic titles and degrees want to seek better opportunities for their career as their process has just begun and they need to experience a long way to achieve their goals (Ramli et al., 2015).

\subsubsection{Internal motivation}

The internal motivation factors of lecturers in researching are summarized as followings:

\section{Getting respect from students, love \& esteem from students}

The repect coming from peers and students has been mentioned in many studies of Chen et al. (2006), Hemmings \& Hill (2009), Hu \& Gill (2000), Tien (2000), Ramli et al. (2015). Chen et al. (2006) states that achieving students' respect is one of many factors that affect the researchers. This is especially true in an environment that researching is the heart of one university. Lecturers with excellent researching results such as books, articles and so on will be considered as highly qualified teachers. As a result, they will receive the respect from their managers, colleagues, students and especially from their society. This respect will motivate them to effort more and focus more on researching projects.

\section{Satisfying one's needs to contribute to new knowledge}

The desire to contribute more new knowledge is also mentioned in many studies of Chen et al. (2006); Hu \& Gill (2000), Ramli et al. (2015). The satisfaction of a lecturer is not only limited in their ability to share and disseminate current knowledge to their students or their society through their lecture or publication. Moreover, the more they can contribute new knowledge that they discover in research to the world, the higher their satisfaction will become. Therefore, the desire to discover new knowledge will motivate lecturers to do more research. (Chen et al., 2006; Hu \& Gill, 2000).

\section{Satisfying need for curiosity}

Researchers do research because they like curiosity (Chen et al., 2006; Hu \& Gill, 2000; Tien, 2000). The curiosity is an extremely important factor that allows researchers build up research questions by themselves and find the way to satisfy their curiosity through doing research.

According to Self-determination theory, Deci \& Ryan (1985) argue that internal motivation is the driving factor of an integration process which firstly distinguishes and then harmoniously combines elements of internal and externals world in its current structure. This integration process requires discovery behaviors to promote the development of research capacity. Therefore, the internal motivation and discovery are considered to be relevant during the development process (Ryan \& Deci, 2000).

Satisfying need to stay current

Chen et al. (2006), Ramli et al. (2015) mention that one of many factors that create research motivation in one field is to meet the currents academic needs. Research projects always require an extremely comprehensive 
overview of related problems; therefore, researchers always predict the current and future development of knowledge in their field. Besides that, by publishing new findings in scientific journals, the expertise and research capacity of one researcher has been largely known, which allows the connection among research community and the connection among current related problems.

\section{Having collaborations with others}

Research projects require a comprehensive overview of related research, therefore, researchers are required to compare, analyze and find knowledge gaps in their research. As a result, the expertise and research capacity of one researcher has been known. This, in turn, will keep the researchers in touch with current and related problems. As a result, they can cooperate with other researchers to study in their similar interested fields (Ramli et al., 2015; Chen et al., 2006).

\section{Joy of involvement}

In general, the joy of work has been mentioned in most studies of work motivation. In particular, the joy of researching has been mentioned in many studies such as Tien (2000), Vallerand (1997), Deci \& Ryan (1985), Wernimont (1972), Zhang (2014). International motivation is synonymous with the desire to work hard, the joy of finishing tasks. In other words, international motivation motivates employees fulfill their tasks to receive international rewards. (Zhang, 2014). Many researchers are attracted by interesting research topics and they are passionate about researching and feeling their excitement while doing research (Tien, 2000).

\section{Responding to challenges}

Tien (2000), Ramli et al. (2015), Ghaoddousi et al. (2014) think the process of doing research helps lecturers solve their difficulties and overcome their obstacles. As a result, they can expand and develop their capacity in new research fields.

\section{Summary of some typical studies relating to motivation}

The majority of studies about lecturers' scientific research motivation consider the effects of internal and external factors to research motivation. However, there are also many studies mention the transition among external and internal motivation based on time. Other studies also find other influential factors. For more details, Bailey (1999) qualitatively examined internal and external motivational factors. Kandiko Howson (2017) also uses qualitative methods to find out that besides internal and external factor, scientific research motivation of lecturers is also affected by "prestige economy" factors - factors that are defined as the impact of social context and university and the confirmation of research community. According to Ryan (2014), scientific research motivation is studied though five aspects of motivation, including (i) Instrumental, (ii) External self-concept, (iii) Intrinsic/ fun/enjoyment, (iv) Internal self-concept and (v) Goal internalization. BlackMore (2011) has reviewed some studies related to scientific research motivation through three main aspects: (i) internal interest, (ii) tangible finance and other benefits and (iii) reputative rewards. The research model of BlackMore (2011) describes the ways monetary and reputable economies interact with each other within a broader academic work and context. Table 1 summaries some typical studies relating to the motivation of researching of lecturers.

Table 1: Summary of some typical studies relating to the motivation of researching of lecturers

\begin{tabular}{|c|c|c|c|c|}
\hline Researchers & $\begin{array}{c}\text { Research } \\
\text { content }\end{array}$ & $\begin{array}{l}\text { Research } \\
\text { approach }\end{array}$ & Research findings & Limitation \\
\hline $\begin{array}{l}\text { Bailey } \\
\text { (1999) }\end{array}$ & $\begin{array}{l}\text { This research } \\
\text { focuses on the } \\
\text { motivation } \\
\text { and } \\
\text { confidence of } \\
\text { lecturers in } \\
\text { lecturing and } \\
\text { researching. }\end{array}$ & $\begin{array}{l}\text { Quantitative method } \\
\text { is used to measure } \\
\text { the motivation and } \\
\text { confidence of } \\
\text { researchers. Data is } \\
\text { analyzed by } \\
\text { STATVIEW II } \\
\text { statistical software, } \\
\text { factor analysis, one- } \\
\text { way analysis of } \\
\text { variance and other } \\
\text { correlation } \\
\text { measurements. }\end{array}$ & $\begin{array}{l}\text { Tutors, lecturers at the level of } \\
\text { bachelor, scholars with low } \\
\text { research capacity and women } \\
\text { have higher motivation of } \\
\text { lecturing. Lecturers has lower } \\
\text { research motivation and } \\
\text { confidence while associate } \\
\text { professors and professors have } \\
\text { the highest research capacity. } \\
\text { Male and female have the } \\
\text { same research capacity and } \\
\text { confidence. Lecturers, who } \\
\text { have higher levels of expertise } \\
\text { and research motivation, also } \\
\text { have higher motivation and } \\
\text { confidence in researching. }\end{array}$ & $\begin{array}{l}\text { Firstly, the sample } \\
\text { size of this research is } \\
\text { small, limiting the } \\
\text { measurement of } \\
\text { research capacity. } \\
\text { Secondly, there is no } \\
\text { specific explanation } \\
\text { about the relationship } \\
\text { between motivation } \\
\text { and confidence. }\end{array}$ \\
\hline
\end{tabular}




\begin{tabular}{|c|c|c|c|c|}
\hline Researchers & $\begin{array}{c}\text { Research } \\
\text { content }\end{array}$ & $\begin{array}{l}\text { Research } \\
\text { approach }\end{array}$ & Research findings & Limitation \\
\hline Tien (2000) & $\begin{array}{l}\text { The } \\
\text { differences } \\
\text { among the } \\
\text { ways } \\
\text { motivation } \\
\text { rewards } \\
\text { motivate } \\
\text { different } \\
\text { lecturers in } \\
\text { different } \\
\text { types of } \\
\text { scientific } \\
\text { research. }\end{array}$ & 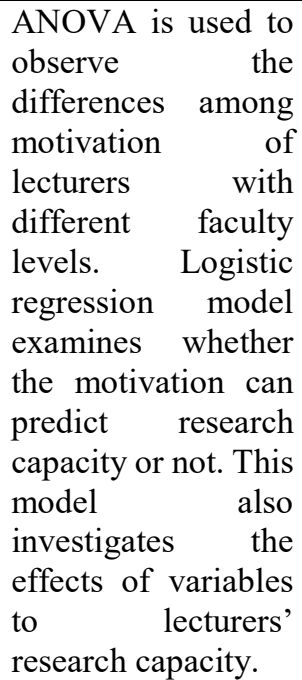 & $\begin{array}{l}\text { The finding results are very } \\
\text { complicated. Different } \\
\text { rewards have different effects } \\
\text { on different types of scientific } \\
\text { research. Lecturers publish } \\
\text { their articles to gain further } \\
\text { promotion and to satisfy their } \\
\text { curiosity. In contrast, they } \\
\text { publish books to show their } \\
\text { expertise and they try to } \\
\text { implement their topic research } \\
\text { to increase their income. }\end{array}$ & $\begin{array}{l}\text { The correlation } \\
\text { among independent } \\
\text { variables has not } \\
\text { been tested such as } \\
\text { the promotion and } \\
\text { expertise value } \\
\text { variables. } \\
\text { The attitude of } \\
\text { lecturers to rewards is } \\
\text { considered to be } \\
\text { constant while Tien } \\
\text { measures valence (V) } \\
\text { and instrumentality } \\
\text { (I) after publishing } \\
\text { his/ her books a } \\
\text { period of time. }\end{array}$ \\
\hline $\begin{array}{l}\text { Chen et al., } \\
(2006)\end{array}$ & $\begin{array}{l}\text { This research } \\
\text { examines the } \\
\text { effects of } \\
\text { motivation } \\
\text { factors to } \\
\text { lecturers' } \\
\text { research } \\
\text { capacity }\end{array}$ & $\begin{array}{l}\text { This research uses } \\
\text { Vroom's } \\
\text { expectancy theory } \\
(1964) \text { and } \\
\text { Regression } \\
\text { technique, in which } \\
\text { the dependent } \\
\text { variable is research } \\
\text { capacity and } \\
\text { independent } \\
\text { variable is research } \\
\text { motivation, to } \\
\text { achieve gradually } \\
\text { 13 listed rewards } \\
\text { motivation. }\end{array}$ & $\begin{array}{l}\text { Tenured faculty members } \\
\text { consider that extrinsic rewards } \\
\text { are more important than } \\
\text { intrinsic rewards. In addition, } \\
\text { (a) untenured faculty members } \\
\text { are motivated by extrinsic } \\
\text { rewards; (b) tenured faculty } \\
\text { members are motivated by } \\
\text { intrinsic rewards; (c) research } \\
\text { productivity has positive } \\
\text { correlation with tenure status } \\
\text { and the percentage of work } \\
\text { time allocated to research } \\
\text { activities and have negative } \\
\text { correlation with employment } \\
\text { time (years); (d) there is no } \\
\text { relationship between research } \\
\text { productivity and academic } \\
\text { discipline; and (e) there is no } \\
\text { relationship between research } \\
\text { productivity and gender. }\end{array}$ & $\begin{array}{l}\text { The singular } \\
\text { regression method } \\
\text { doesn't show that } \\
\text { rewards } \\
\text { motivation are the } \\
\text { most important } \\
\text { factors in explaining } \\
\text { the changes of } \\
\text { publications among } \\
\text { lecturers. }\end{array}$ \\
\hline $\begin{array}{l}\text { Lertputtarak } \\
(2006)\end{array}$ & $\begin{array}{l}\text { This research } \\
\text { focuses on } \\
\text { factors that } \\
\text { affect } \\
\text { lecturers' } \\
\text { research } \\
\text { capacity in } \\
\text { one public } \\
\text { university in } \\
\text { Thailand. }\end{array}$ & $\begin{array}{l}\text { Based on Vroom's } \\
\text { expectancy theory } \\
\text { and the self- } \\
\text { confidence theory, } \\
\text { this research finds } \\
\text { factors that affect } \\
\text { the productivity of } \\
\text { scientific research. } \\
\text { Qualitative research } \\
\text { methods and in- } \\
\text { depth interviews } \\
\text { have been applied } \\
\text { with eleven } \\
\text { representatives from } \\
\text { Noble Public } \\
\text { University. }\end{array}$ & $\begin{array}{l}\text { From the research overview, } \\
\text { there are five important factors } \\
\text { that affect the research } \\
\text { capacity. These factors include } \\
\text { environment, institution, } \\
\text { personal career development, } \\
\text { preventive society and } \\
\text { demography. According to this } \\
\text { research's results, these five } \\
\text { factors can be divided into } \\
\text { three main groups, including } \\
\text { essential factors, desired } \\
\text { factors and other influencing } \\
\text { factors. Each factor is } \\
\text { confirmed to be solved in a } \\
\text { sequential order } \\
\text { university's managers. }\end{array}$ & $\begin{array}{l}\text { This research is } \\
\text { limited in only one } \\
\text { university and is } \\
\text { considered as a } \\
\text { typical case. It is } \\
\text { quite difficult to have } \\
\text { accurate information } \\
\text { of research } \\
\text { productivity from } \\
\text { each department. }\end{array}$ \\
\hline
\end{tabular}




\begin{tabular}{|c|c|c|c|c|}
\hline Researchers & $\begin{array}{c}\text { Research } \\
\text { content }\end{array}$ & $\begin{array}{l}\text { Research } \\
\text { approach }\end{array}$ & Research findings & Limitation \\
\hline $\begin{array}{l}\text { Blackmore } \\
\& \quad \text { Kandiko } \\
(2011)\end{array}$ & $\begin{array}{l}\text { The working } \\
\text { model of an } \\
\text { academic } \\
\text { team is based } \\
\text { on } \\
\text { overviewing } \\
\text { documents. }\end{array}$ & $\begin{array}{l}\text { Summary from the } \\
\text { results of previous } \\
\text { research. }\end{array}$ & $\begin{array}{l}\text { This research model focuses } \\
\text { on three main aspects: internal } \\
\text { factors; finance, other tangible } \\
\text { benefits and reputative } \\
\text { rewards. This model describes } \\
\text { different ways that reputative } \\
\text { monetary economics interact } \\
\text { with each other, with broader } \\
\text { academic work and contexts. } \\
\text { The term of "Prestige } \\
\text { economy" is related to a } \\
\text { system of valuating and } \\
\text { exchanging a variety of capital } \\
\text { forms in an academic context. }\end{array}$ & $\begin{array}{l}\text { This research mainly } \\
\text { focuses on working } \\
\text { motivation level } \\
\text { personal at } \\
\text { without mentioning } \\
\text { organizational levels. } \\
\text { There is a need to } \\
\text { have more tests and } \\
\text { more model } \\
\text { development. }\end{array}$ \\
\hline $\begin{array}{l}\text { Pasupathy \& } \\
\text { Siwatu } \\
(2014)\end{array}$ & $\begin{array}{l}\text { This research } \\
\text { is about the } \\
\text { confidence } \\
\text { and its effects } \\
\text { on research } \\
\text { productivity } \\
\text { of lecturers at } \\
\text { an emerging } \\
\text { university in } \\
\text { US. }\end{array}$ & $\begin{array}{l}\text { This research uses } \\
\text { social recognition } \\
\text { theory, specifically } \\
\text { the theory of } \\
\text { confidence. } \\
\text { Quantitative } \\
\text { analysis method and } \\
\text { descriptive } \\
\text { statistical analysis } \\
\text { are used to evaluate } \\
\text { the relationship } \\
\text { between the } \\
\text { confidence and } \\
\text { research } \\
\text { productivity. }\end{array}$ & $\begin{array}{l}\text { There is a significant but small } \\
\text { correlation between the } \\
\text { confidence and research } \\
\text { productivity. }\end{array}$ & $\begin{array}{l}\text { The importance of } \\
\text { expertise needs to be } \\
\text { emphasized in } \\
\text { qualitative analysis. } \\
\text { Sample size is small } \\
\text { and research } \\
\text { productivity is } \\
\text { measured through } \\
\text { self -assessment. }\end{array}$ \\
\hline Ryan (2014) & $\begin{array}{l}\text { This research } \\
\text { is about (1) } \\
\text { the working } \\
\text { motivation of } \\
\text { scientists, (2) } \\
\text { the } \\
\text { relationship } \\
\text { between } \\
\text { motivation } \\
\text { aspects and } \\
\text { demographic } \\
\text { variables and } \\
\text { (3) the impact } \\
\text { of working } \\
\text { motivation to } \\
\text { research } \\
\text { productivity. }\end{array}$ & $\begin{array}{l}\text { This research uses } \\
\text { qualitative research } \\
\text { with a motivation } \\
\text { scale in five aspects: } \\
\text { Instrumental, } \\
\text { External self- } \\
\text { concept, Intrinsic/ } \\
\text { fun/enjoyment, } \\
\text { internal self-concept } \\
\text { and Goal } \\
\text { internalization. } \\
\text { Besides that, EFA, } \\
\text { CFA, and SEM are } \\
\text { also used. }\end{array}$ & $\begin{array}{l}\text { Internal and external } \\
\text { motivation is the strongest and } \\
\text { the weakest respectively for } \\
\text { different scientists. External } \\
\text { motivation is found to be } \\
\text { significantly higher than } \\
\text { internal motivation among } \\
\text { younger scientists. There is no } \\
\text { gender difference in the } \\
\text { motivation of scientists. While } \\
\text { controlling the influences of } \\
\text { age and gender, internal } \\
\text { motivation is found to have } \\
\text { significant positive effect on } \\
\text { research performance while } \\
\text { external motivation is found to } \\
\text { have significant negative } \\
\text { effect on research } \\
\text { performance. Differences in } \\
\text { research across age and gender } \\
\text { are also identified. }\end{array}$ & $\begin{array}{l}\text { The sample doesn't } \\
\text { represent for all } \\
\text { scientists in all } \\
\text { research fields. } \\
\text { Furthermore, the } \\
\text { research is lack of } \\
\text { empirical research to } \\
\text { examine working } \\
\text { motivation } \\
\text { scientists and has } \\
\text { relatively } \\
\text { variances, } \\
\text { requires low } \\
\text { complex } \\
\text { variables analysis. }\end{array}$ \\
\hline
\end{tabular}




\begin{tabular}{|c|c|c|c|c|}
\hline Researchers & $\begin{array}{c}\text { Research } \\
\text { content }\end{array}$ & $\begin{array}{l}\text { Research } \\
\text { approach }\end{array}$ & Research findings & Limitation \\
\hline $\begin{array}{l}\text { Zhang } \\
\text { (2014) }\end{array}$ & $\begin{array}{l}\text { The research } \\
\text { studies } \\
\text { factors that } \\
\text { motivate } \\
\text { lecturers to } \\
\text { conduct } \\
\text { research and } \\
\text { influence } \\
\text { their research } \\
\text { productivity }\end{array}$ & $\begin{array}{l}\text { The research } \\
\text { combines } \\
\text { qualitative and } \\
\text { quantitative } \\
\text { method. ANOVA } \\
\text { analysis is used to } \\
\text { examine the } \\
\text { differences of } \\
\text { dependent variables } \\
\text { based on the degree } \\
\text { of independent } \\
\text { variables and test } \\
\text { the differences } \\
\text { among internal and } \\
\text { external motivation } \\
\text { factors of lecturers. }\end{array}$ & $\begin{array}{l}\text { The finding results show that } \\
\text { motivation of higher level } \\
\text { academic staff is mainly } \\
\text { affected by internal factors, } \\
\text { while the motivation of higher } \\
\text { level academic staff is mainly } \\
\text { affected by external factors. } \\
\text { However, internal factors also } \\
\text { have an impact on lower level } \\
\text { academic staff. Research } \\
\text { productivity is also affected by } \\
\text { many factors. Lecturers at } \\
\text { different positions or different } \\
\text { academic levels have different } \\
\text { impacts. The qualitative } \\
\text { results show a deep } \\
\text { understanding of the } \\
\text { motivation of lecturers at } \\
\text { different academic levels. }\end{array}$ & $\begin{array}{l}\text { The sample size and } \\
\text { range are narrow. } \\
\text { This research only } \\
\text { studies factors that } \\
\text { affect the motivation } \\
\text { and productivity but } \\
\text { ignore the } \\
\text { satisfaction of } \\
\text { lecturers because } \\
\text { higher satisfaction } \\
\text { will lead to higher } \\
\text { motivation and } \\
\text { productivity. }\end{array}$ \\
\hline $\begin{array}{l}\text { Howson \& et } \\
\text { al }(2017)\end{array}$ & $\begin{array}{l}\text { This research } \\
\text { studies the } \\
\text { motivation of } \\
\text { academic } \\
\text { staff by } \\
\text { looking at the } \\
\text { way internal } \\
\text { and external } \\
\text { factors } \\
\text { enriched by } \\
\text { exploring } \\
\text { education } \\
\text { context. }\end{array}$ & $\begin{array}{l}\text { This research uses } \\
\text { qualitative research } \\
\text { method and } \\
\text { interviews of } \\
\text { motivation to find } \\
\text { out why scientists } \\
\text { attend academic } \\
\text { work while } \\
\text { completing other } \\
\text { tasks like managing } \\
\text { and continuing their } \\
\text { job, although they } \\
\text { can meet many } \\
\text { challenges at many } \\
\text { levels. }\end{array}$ & $\begin{array}{l}\text { This research notes that there } \\
\text { are also factors related to } \\
\text { academic contexts and fields } \\
\text { that going together with clear } \\
\text { internal factors (like the } \\
\text { academic curiosity) and } \\
\text { external factors (like financial } \\
\text { rewards). The researcher has } \\
\text { suggested that the term of } \\
\text { "prestige economy" supports } \\
\text { the description of context - } \\
\text { which is created by academic } \\
\text { society and culture. }\end{array}$ & $\begin{array}{l}\text { Managers should } \\
\text { analyze the role and } \\
\text { responsibility of } \\
\text { gender in their } \\
\text { organization, } \\
\text { including union } \\
\text { activities and support } \\
\text { programs } \\
\text { students. }\end{array}$ \\
\hline
\end{tabular}

\section{References}

Adler, N. J. (2008). International dimensions of organizational behavior. 5th Ed. Mason, Ohio: Thompson, Southwest.

Bailey, J. G. (1999). Academics motivation and self-efficacy for teaching and research, Higher Education Research \& Development, 18(3), 343-359.

Baker, T. L. (1994), Doing Social Research. $2^{\text {nd }}$ ed. New York: McGraw-Hill Inc.

Baron, R. A. (1983). Behavior in organizations. New York.

Bentley, R. J. \& Blackburn, R. T. (1991). Changes in academic research performance over time: A study of institutional accumulated advantage, Research in Higher Education, 31(4), 327-353.

Bess, J. L. (1998). Contract systems, bureaucracies, and faculty motivation: The probable effects of a no-tenure policy, The Journal of Higher Education, 69(1), 1-22.

Blackburn, R. T., \& Lawrence, J. H. (1995). Faculty at work: Motivation, expectation, satisfaction. Johns Hopkins University Press.

Blackmore, P., \& Kandiko, C. B. (2011). Motivation in academic life: A prestige economy. Research in PostCompulsory Education, 16(4), 399-411.

Butkus, R. T., \& Green, T. B. (1999). Motivation, beliefs and organizational transformation. Greenwood publishing group.

Brewer, P. D., Brewer, V. L., \& Hilton, C. (1990). Promoting research productivity in colleges of business, Journal of Education for Business, 66(1), 52-56.

Broder, J. M., \& Ziemer, R. F. (1982). Determinants of agricultural economics faculty salaries. American Journal of Agricultural Economics, 64(2), 301-303.

Cargile, B. R., \& Bublitz, B. (1986). Factors contributing to published research by accounting faculties, Accounting 
Review, 158-178.

Chen, Y. \& Gupta, A. \& Hoshower, L. (2006), Factors that motivate Business Faculty to conduct research: An expectancy Theory Analysis, Journal of Education for Business, 81(4), 179-189.

Chiang, C. F., \& Jang, S. S. (2008). An expectancy theory model for hotel employee motivation, International Journal of Hospitality Management, 27(2), 313-322.

Cooper, H. M., \& Burger, J. M. (1980). How teachers explain students' academic performance: A categorization of free response academic attributions, American Educational Research Journal, 17(1), 95-109.

Creswell, J. W. (1986). Concluding thoughts: Observing, promoting, evaluating, and reviewing research performance, New Directions for Institutional Research, 1986(50), 87-102.

Deci, E. L., \& Ryan, R. M. (1985). The general causality orientations scale: Self-determination in personality, Journal of research in personality, 19(2), 109-134.

Deeprose, D. (1994). How to Recognize \& Reward Employees. New York. NY: Amacom, American Management Association.

Dennis, A. R., Valacich, J. S., Fuller, M. A., \& Schneider, C. (2006). Research standards for promotion and tenure in information systems, Mis Quarterly, 1-12.

Feldman, K. A., \& Paulsen, M. B. (1999). Faculty motivation: The role of a supportive teaching culture, New directions for teaching and learning, 1999(78), 69-78.

Fox, M. F. (1985). Publication, performance, and reward in science and scholarship. Higher education: Handbook of theory and research, 1, 255-282.

George, J. M., Jones, G. R., \& Sharbrough, W. C. (2005). Understanding and managing organizational behavior. Upper Saddle River, NJ: Pearson Prentice Hall.

Ghoddousi, P., Bahrami, N., Chileshe, N., \& Hosseini, M. R. (2014), Mapping site-based construction workers' motivation: Expectancy theory approach, Australasian Journal of Construction Economics and Building, 14 (1) $60-77$

Greenberg, E. R., Baron, J. A., DH Jr, F., Mandel, J. S., \& Haile, R. (1993). Reduced risk of large-bowel adenomas among aspirin users, JNCI: Journal of the National Cancer Institute, 85(11), 912-915.

Hemmings, B., \& Hill, D. (2009). The development of lecturer research expertise: Towards a unifying model, Issues in Educational Research, 19(1), 14-24.

Henley, J. S., \& Nyaw, M. K. (1986). Introducing Market Forces into Managerial Decision-Making in Chinese Industrial Enterprises, Journal of Management Studies, 23(6), 635-656.

Hu, Q., \& Gill, G.T. (2000). "Is faculty research productivity: Influential factors and implications", Information Resources Management Journal, 13(2), 15-25.

James, I. J. (2011). Effective motivation of paraprofessional staff in academic libraries in Nigeria. Library Philosophy and Practice. ISSN 1522-0222.

Howson, K., Coate, K., \& Croix, T. (2018). Mid-career academic women and the prestige economy. Higher Education Research \& Development, 37(3), 533-548.

Khan, S. Z. (2011), Factors Affecting the Motivation of Expatriate English as a Foreign Language (EFL) Teachers in the Sultanate of Oman. $\mathrm{PhD}$ Thesis. University of Exeter.

Kreitner, R., \& Kinicki, A. (2001). Organizational behavior (5 ${ }^{\text {th }}$ Ed). McGraw-Hill companies, Inc.

La Motta, T. (1995). Recognition: The quality way. New York: Quality Resources.

Lawler E.E. (2003). Treat people right. San Francisco: Jossey-Bass Inc.

Lockwood, P. (2005). Promoting success or preventing failure: Cultural differences in motivation by positive and negative role models. Personality and Social Psychology Bulletin 31: 379-392.

Lertputtarak, S. (2008). An investigation of factors related to research productivity in a public university in Thailand: A case study, PhD Thesis, Victoria University.

Mallaiah, T. Y., \& Yadapadithaya, P. S. (2009). Intrinsic motivation of librarians in university libraries in Karnataka, Journal of Library \& Information Technology, 29(3), 36.

Mitchell, T. R., \& Albright, D. W. (1972). Expectancy theory predictions of the satisfaction, effort, performance, and retention of naval aviation officers, Organizational Behavior and Human Performance, 8(1), 1-20.

Mitchell, T. R. (1997). Matching motivational strategies with organizational contexts. Research in organizational behavior, 19, 57-150.

Mol, A. (1992). Motivating subordinates, IPM Journal, 11 (2), 19-22.

Olorunsola, R., \& Bamijoko, S. B. (2005). Recruitment and retention of librarians in Nigeria: The huddles ahead, Middle Belt Journal of Library and Information Science, 5(1), 9-15.

Pasupathy, R., \& Siwatu, K. O. (2014). An investigation of research self-efficacy beliefs and research productivity among faculty members at an emerging research university in the USA, Higher Education Research \& Development, 33(4), 728-741.

Ramli, M. S. B., \& Jusoh, A. B. (2015). Expectancy theory analysis to conduct research at Malaysian Research University, International Journal of Economics and Financial Issues, 5(1S). 
Robbins \& Judge. (2008). Organization behavior. $13^{\text {th }}$ Ed. Upper Saddle River, New Jersey: Pearson Prentice Hall manager. Industrial Relations, 2(2), 95-117.

Ruscio, K. P. (1987). The distinctive scholarship of the selective liberal arts college, The Journal of Higher Education, 58(2), 205-222.

Ryan, R. M., \& Deci, E. L. (2000). Self-determination theory and the facilitation of intrinsic motivation, social development, and well-being, American Psychologist, 55, 68-78.

Ryan, J. C. (2014). The work motivation of research scientists and its effect on research performance. $R \& D$ Management, 44(4), 355-369.

Santo, S. A., Engstrom, M. E., Reetz, L., Schweinle, W. E., \& Reed, K. (2009). Faculty productivity barriers and supports at a school of education, Innovative Higher Education, 34(2), 117-129.

Sharpes, D. K. (1987). Incentive pay and the promotion of teaching proficiencies, The Clearing House, 60(9), 406408.

Tien, F.F. (2000). To what degree does the desire for promotion motivate faculty to perform research?, Research in Higher Education, 41(6), 723-752.

Tien, F.F., \& Blackburn, R.T. (1996). Faculty rank system, research motivation, and faculty research productivity: Measurement refinement and theory testing, Journal of Higher Education, 67(1), 2-22.

Vallerand, R. J. (1997). Toward a hierarchical model of intrinsic and extrinsic motivation, Advances in experimental social psychology, 29, 271-360.

Vroom, V. H. (1964), Work and motivation, New York, Wiley, USA.

Wernimont, P. F. (1972). A systems view of job satisfaction, Journal of Applied Psychology, 56(2), 173.

Williams, A. (2003), A mediated hierarchical regression analysis of factors related to research productivity of human resource education and workforce development postsecondary faculty. Doctoral Dissertation, Lousiana State University and Agricultural and Mechanical College. Retrieved from UMI Database.

Zhang, X. (2014). Factors that Motivate Academic Staff to Conduct Research and Influence Research Productivity in Chinese Project 211 Universities. PhD Thesis, University of Canberra. 